\title{
PENGARUH GAYA KEPEMIMPINAN, LINGKUNGAN KERJA DAN MOTIVASI TERHADAP KEPUASAN KERJA KARYAWAN PADA PT ASTRA DAIHATSU CABANG PASAR MINGGU
}

\author{
Jason Paendong ${ }^{1}$ \\ Endri Sentosa ${ }^{2}$ \\ Sarpan $^{3}$ \\ ${ }^{1,2,3}$ Fakultas Ekonomi dan Bisnis Universitas Persada Indonesia (YAI) Jakarta \\ Email: esanuansa@yahoo.com ${ }^{2}$
}

\begin{abstract}
ABSTRAK
Penelitian ini bertujuan untuk menganalisis pengaruh gaya kepemimpinan, lingkungan kerja, dan motivasi terhadap kepuasan kerja karyawan pada PT Astra Daihatsu Cabang Pasar Minggu. Sampel yang digunakan adalah 80 karyawan PT Astra Daihatsu Cabang Pasar Minggu. Hasil penelitian menunjukkan bahwa gaya kepemimpinan, lingkungan kerja, dan motivasi secara parsial berpengaruh positif dan signifikan terhadap kepuasan kerja karyawan pada PT Astra Daihatsu Cabang Pasar Minggu.
\end{abstract}

Kata kunci: Gaya kepemimpinan, lingkungan kerja, motivasi, kepuasan kerja karyawan

\section{ABSTRACT}

This research aims to analyze the effect of leadership style, work environment, and motivation on work satisfaction of employees at Pasar Minggu Branch of PT Astra Daihatsu. The sample used are 80 employees of PT Astra Daihatsu at Pasar Minggu Branch. Results of the research showed that leadership style, work environment, and motivation partially has positive and significant effect on work satisfaction of employees at Pasar Minggu Branch of PT Astra Daihatsu.

Keywords: Leadership style, work environment, and motivation, work satisfaction of employees

\section{PENDAHULUAN}

Sumber daya manusia merupakan salah satu faktor penting yang perlu untuk senantiasa diperhatikan dalam suatu perusahaan karena setiap upaya pencapaian visi perusahaan dengan jalan pelaksanaan misi pada dasarnya diatur oleh manusia. Oleh sebab itu, perusahaan harus mampu mengoptimalkan kinerja sumber daya manusianya agar mampu untuk mencapai visi dan tujuan yang telah ditetapkan dengan tanpa terkendala oleh hambatan-hambatan. Dalam kaitannya dengan hal ini, maka perusahaan juga perlu untuk senantiasa menjamin kepuasan karyawannya karena kepuasan karyawan itu sendiri mencerminkan bahwa karyawan merasa senang dan cinta dengan pekerjaanya, sehingga akan mendorong karyawan tersebut untuk menunjukkan moral, disiplin, dan prestasi kerja yang tinggi yang pada akhirnya juga akan menimbulkan kinerja yang tinggi. 
PT Astra Daihatsu Motor (ADM) merupakan Agen Tunggal Pemegang Merk mobil Daihatsu di Indonesia yang satu-satunya berhak untuk mengimpor, merakit, dan memproduksi kendaraan bermerek Daihatsu di Indonesia. Perusahaan ini merupakan perusahaan joint venture antara Daihatsu Motor Company dan Astra International yang telah didirikan sejak 1978. Dalam kegiatan operasionalnya, PT Astra Daihatsu Motor memiliki banyak cabang yang salah satunya ada di Pasar Minggu. Setiap cabang tersebut secara bersama-sama berperan untuk membantu PT Astra Daihatsu Motor dalam mencapai visi dan tujuannya.

Sebagaimana halnya pada perusahaan lainnya, kepuasan kerja karyawan juga merupakan hal penting yang perlu diperhatikan oleh PT Astra Daihatsu Motor dalam memanage sumber daya manusianya. Dalam hal ini, tingkat kepuasan kerja karyawan itu sendiri dapat diamati berdasarkan tingkat absensi dari para karyawan sebagaimana yang ditunjukkan pada tabel berikut.

Tabel 1. Daftar Absen Kehadiran Karyawan PT Astra Daihatsu Cabang Pasar Minggu Periode 2017-2018

\begin{tabular}{|c|l|r|r|}
\hline \multirow{2}{*}{ No. } & \multirow{2}{*}{ Bulan } & \multicolumn{2}{c|}{ Kehadiran (\%) } \\
\cline { 3 - 4 } & & $\mathbf{2 0 1 7}$ & $\mathbf{2 0 1 8}$ \\
\hline 1 & Januari & 99,7 & 78,7 \\
\hline 2 & Februari & 99,7 & 79,5 \\
\hline 3 & Maret & 100,0 & 79,8 \\
\hline 4 & April & 100,0 & 81,8 \\
\hline 5 & Mei & 99,9 & 85,8 \\
\hline 6 & Juni & 100,0 & 89,9 \\
\hline 7 & Juli & 100,0 & 83,9 \\
\hline 8 & Agustus & 99,6 & 78,7 \\
\hline 9 & September & 99,8 & 88,9 \\
\hline 10 & Oktober & 100,0 & 92,7 \\
\hline 11 & November & 99,9 & 88,8 \\
\hline 12 & Desember & 99,7 & 92,4 \\
\hline \multicolumn{2}{|c|}{ Nilai Rata-Rata } & $\mathbf{9 9 , 8 5}$ & $\mathbf{8 5 , 0 7}$ \\
\hline
\end{tabular}

Berdasarkan tabel di atas, rata-rata tingkat kehadiran pada periode tersebut mengalami penurunan sebesar 14,78\%, yakni dari 99,85\% di tahun 2017 menjadi 85,07\% di tahun 2018. Hal ini dapat menjadi indikasi awal atas adanya penurunan kepuasan kerja karyawan yang dapat saja disebabkan oleh berbagai variabel yang relevan. Agar dapat meningkatkan kepuasan kerja karyawannya, maka perusahaan harus memanfaatkan berbagai variabel yang relevan tersebut secara efektif. 
Salah satu variabel yang mampu mempengaruhi kepuasan kerja karyawan adalah variabel gaya kepemimpinan. Hal tersebut dilandasi oleh hasil penelitian yang dilakukan oleh Yanoto (2018) yang menunjukkan bahwa gaya kepemimpinan berpengaruh positif dan signifikan terhadap kepuasan kerja karyawan. Pada dasarnya, gaya kepemimpinan mampu mempengaruhi kepuasan kerja karyawan karena gaya kepemimpinan itu sendiri akan menentukan pendekatan yang akan dipergunakan oleh seorang pemimpin perusahaan dalam mengarahkan karyawan yang dipimpinnya untuk mencapai suatu tujuan, sehingga apabila gaya kepemimpinan yang diterapkan tidaklah tepat, maka pendekatan yang dipergunakan oleh pimpinan tersebut pun menjadi tidak tepat, sehingga dapat menimbulkan ketidakpuasan di dalam diri karyawan yang bersangkutan.

Variabel lingkungan kerja juga mampu mempengaruhi kepuasan kerja karyawan sebagaimana dengan hasil penelitian yang dilakukan oleh Sitinjak (2018) yang menunjukkan bahwa variabel tersebut secara positif dan signifikan berpengaruh terhadap kepuasan kerja karyawan. Dalam hal ini, lingkungan kerja yang baik tidak hanya mampu untuk menunjang dan mendukung pelaksanaan tugas dan pekerjaan oleh karyawan dalam perusahaan, tetapi juga akan mampu memberikan keamanan dan kenyamanan bagi karyawan tersebut yang pada akhirnya akan menimbulkan perasaan puas di dalam diri karyawan yang bersangkutan.

Variabel lainnya yang mampu mempengaruhi kepuasan kerja karyawan adalah variabel motivasi sebagaimana yang dibuktikan oleh Parimita, dkk. (2018) dalam penelitiannya yang menunjukkan bahwa variabel motivasi tersebut berpengaruh positif dan signifikan terhadap kepuasan kerja karyawan. Dalam hal ini, motivasi tepat yang diberikan oleh perusahaan kepada karyawannya akan mendorong karyawan untuk menyenangi pekarjaannya atau dengan kata lain motivasi tersebut akan mampu membuat karyawan yang bersangkutan merasa puas dengan pekerjaan yang dijalaninya.

Berdasarkan uraian latar belakang di atas, perlu dilakukan penelitian untuk menganalisis pengaruh gaya kepemimpinan, lingkungan kerja, dan motivasi terhadap kepuasan kerja karyawan pada PT Astra Daihatsu Cabang Pasar Minggu.

\section{TINJAUAN PUSTAKA}

\section{Gaya Kepemimpinan}

Menurut Robbins dan Judge (2008), kepemimpinan merupakan kemampuan dalam mempengaruhi kelompok untuk mencapai suatu visi dan tujuan. Adapun yang dimaksud 
dengan gaya kepemimpinan menurut Moeheriono (2012) adalah suatu pola tingkah laku dari pemimpin yang berhubungan dengan kemampuannya dalam memimpin. Gaya kepemimpinan juga bisa didefinisikan sebagai sekelompok ciri dari seorang pemimpin dalam mempengaruhi bawahannya untuk mencapai suatu sasaran yang sudah ditetapkan oleh organisasi (Rivai dan Mulyadi, 2012).

Menurut Robbins (2003), terdapat empat tipe kepemimpinan, yakni sebagai berikut.

1. Kepemimpinan karismatik, yakni tipe yang menarik pengikutnya dengan mempergunakan gaya yang heroik/luar biasa.

2. Kepemimpinan transaksional, yakni tipe yang memandu dan memotivasi pengikutnya untuk mencapai suatu sasaran dengan menguraikan kebutuhan tugas dan perannya.

3. Kepemimpinan transformasional, yakni tipe yang secara mendalam menginspirasi pengikutnya untuk melampaui kepentingan pribadi mereka sendiri.

4. Kepemimpinan visioner, yakni tipe yang membuat dan mengkomunikasikan visi yang realistis, kredibel dan menarik.

\section{Lingkungan Kerja}

Lingkungan kerja didefinisikan oleh Sutrisno (2010) sebagai semua sarana dan prasarana kerja di sekitar karyawan yang mampu mempengaruhi pelaksanaan pekerjaan, mulai dari tempat kerja itu sendiri, fasilitas, alat bantu kerja, kebersihan, pencahayaan, ketenangan, dan hubungan kerja dengan orang-orang di tempat tersebut. Menurut Sofyandi (2008:38), lingkungan kerja merupakan faktor internal yang mampu mempengaruhi kinerja SDM.

Faktor-faktor yang bisa mempengaruhi lingkungan kerja antara lain oleh Tyssen (2003) dalam Sofyan (2013:20) dikemukakan sebagai berikut.

1. Fasilitas Kerja

Lingkungan kerja yang kurang mendukung pelaksanaan pekerjaan, seperti ruang kerja yang pengap, tidak dilengkapi dengan ventilasi dan alat kerja yang memadai, serta tidak ditunjang oleh prosedur kerja yang jelas pada akhirnya akan turut mengakibatkan kinerja yang buruk. 
2. Gaji dan Tunjangan

Gaji yang tidak sesuai dengan ekspektasi karyawan akan mengakibatkan karyawan tersebut untuk cenderung berupaya mencari pekerjaan lain agar dapat memenuhi ekspektasi kerjanya.

3. Hubungan Kerja

Kelompok kerja yang kompak dan loyal akan bisa meningkatkan kinerja karyawan karena setiap karyawan akan saling mendukung pencapaian tujuan masing-masing.

Menurut Nitisemito (2000:127) dalam Nuraini (2013:97), indikator lingkungan kerja antara lain terdiri dari hal-hal sebagai berikut.

1. Pencahayaan, yakni penerangan yang memadai bagi pekerjaan yang membutuhkan tingkat ketelitian tinggi.

2. Suhu udara, yakni suhu udara yang tepat untuk mempertahankan kondisi normal dari sistem di dalam tubuh karyawan.

3. Kebisingan, dimana dalam hal ini, lingkungan kerja yang bising bisa mengganggu konsentrasi karyawan dalam bekerja.

4. Tata ruang, yakni tataan, warna, dan kebersihan dari setiap ruangan yang mampu mempengaruhi karyawan dalam menjalankan pekerjaannya.

5. Hubungan karyawan.

\section{Motivasi}

Motivasi berasal dari bahasa latin, yakni dari kata "movere" yang artinya dorongan atau menggerakkan. Secara istilah, motivasi adalah pendayagerakkan kegairahan kerja dari seseorang agar bersedia untuk bekerja sama, bekerja secara efektif, dan berintegrasi untuk mencapai suatu kepuasan (Hasibuan, 2014). Menurut Robbins dan Judge (2008), motivasi merupakan suatu proses untuk mengartikulasi intensitas, arah, dan ketekunan dalam mencapai tujuan. Adapun oleh Bangun (2012:312), motivasi didefinisikan sebagai suatu situasi yang mendorong pelaksanaan tugas oleh seseorang sesuai dengan fungsinya di dalam organisasi.

Menurut Hasibuan (2014:146), motivasi memiliki azas-azas tersendiri, yakni sebagai berikut. 
1. Azas mengikutsertakan, yakni azas yang mengajak karyawan untuk berpartisipasi dan memberikan mereka kesempatan untuk memberi ide serta saran dalam pengambilan keputusan.

2. Azas komunikasi, yakni azas yang secara jelas mengkomunikasikan tujuan, cara untuk mencapainya, serta hambatan dalam proses pencapaian tersebut.

3. Azas pengakuan, yakni azas yang memberi penghargaan dan rekognisi yang tepat atas prestasi kerja karyawan.

4. Azas wewenang dan delegasi, yakni azas yang mendelegasikan wewenang dan kebebasan bagi karyawan dalam pengambilan keputusan dan penciptaan kreasi.

5. Azas perhatian timbal balik, yakni azas yang memotivasi karyawan dengan jalan mengemukakan harapan perusahaan dan dengan berusaha untuk memenuhi kebutuhan yang diekspektasikan oleh karyawan tersebut.

Dalam memotivasi, ada dua metode yang menurut Hasibuan (2014:149) dapat dipergunakan, yakni sebagai berikut.

1. Motivasi langsung (direct motivation), yaitu motivasi (materil dan nonmateril) bersifat khusus yang diberikan secara langsung kepada karyawan untuk memenuhi kebutuhan dan kepuasannya, misalnya seperti pujian, penghargaan, tunjangan hari raya, bonus, dan bintang jasa.

2. Motivasi tidak langsung (indirect motivation), yaitu motivasi yang dilakukan dengan cara memberikan fasilitas pendukung dan penunjang kelancaran dan gairah kerja kepada karyawan, sehingga karyawan tersebut betah dan bersemangat dalam menjalankan tugas dan pekerjaannya.

\section{Kepuasan Kerja Karyawan}

Menurut Hasibuan (2014), kepuasan kerja adalah perasaan senang dan cinta terhadap suatu pekerjaan yang dicerminkan oleh moral, disiplin, dan prestasi kerja. Wibowo (2010:501) mendefinisikan kepuasan kerja sebagai suatu sikap pekerja terhadap suatu pekerjaan yang mencerminkan selisih antara penghargaan yang diterimanya dengan apa yang diyakini pekerja tersebut seharusnya diterimanya. Adapun Handoko (2012:193) mengartikan kepuasan kerja sebagai suatu kondisi emosional karyawan yang merasa senang atau tidak senang dalam melihat pekerjaannya. 
Menurut Hariandja (2005:291), terdapat beberapa faktor yang mampu mempengaruhi kepuasan kerja, di antaranya ialah sebagai berikut.

1. Gaji, yaitu mencakup kesesuaian dan keadilan dari bayaran yang diterima oleh seseorang atas pekerjaannya.

2. Pekerjaan itu sendiri, yaitu mencakup kepuasan terhadap pekerjaan yang dijalani.

3. Rekan sekerja, yakni teman interaksi dalam bekerja.

4. Atasan, yakni orang yang memberikan perintah/petunjuk mengenai pelaksanaan kerja.

5. Promosi, yakni mencakup probabilitas seseorang untuk berkembang melalui kenaikan tingkat jabatan.

6. Lingkungan kerja, yakni meliputi lingkungan fisik dan psikologis.

\section{Keterkaitan Antarvariabel Penelitian}

\section{Keterkaitan antara Gaya Kepemimpinan dan Kepuasan Kerja}

Hasil penelitian yang dilakukan oleh Yanoto (2018) menunjukkan bahwa gaya kepemimpinan berpengaruh positif dan signifikan terhadap kepuasan kerja karyawan. Hal tersebut terjadi karena gaya kepemimpinan itu sendiri akan menentukan pendekatan yang akan dipergunakan oleh seorang pemimpin perusahaan dalam mengarahkan karyawan yang dipimpinnya untuk mencapai suatu tujuan, sehingga apabila gaya kepemimpinan yang diterapkan tidaklah tepat, maka pendekatan yang dipergunakan oleh pimpinan tersebut pun menjadi tidak tepat, sehingga dapat menimbulkan ketidakpuasan di dalam diri karyawan yang bersangkutan. Sebaliknya, pada perusahaan yang menerapkan gaya kepemimpinan yang tepat, misalnya dalam bentuk gaya kepemimpinan demokratis, Nopitasari dan Krisnandi (2018) mengemukakan bahwa karyawan cenderung akan merasa dilibatkan oleh pimpinannya. Hal tersebut pada akhirnya dapat menimbulkan kepuasan bagi karyawan karena karyawan merasa dirinya dianggap oleh perusahaan tempatnya bekerja dan bahkan diberikan tanggung jawab untuk terlibat dalam pengambilan keputusan.

$\mathrm{H}_{1}$ : Gaya kepemimpinan berpengaruh positif dan signifikan terhadap kepuasan kerja karyawan pada PT Astra Daihatsu Cabang Pasar Minggu

\section{Keterkaitan antara Lingkungan Kerja dan Kepuasan Kerja}

Lingkungan kerja mampu mempengaruhi kepuasan kerja karyawan sebagaimana dengan hasil penelitian yang dilakukan oleh Sitinjak (2018) yang menunjukkan bahwa variabel tersebut secara positif dan signifikan berpengaruh terhadap kepuasan kerja 
karyawan. Dalam kaitannya dengan hal ini, Rivai dan Sagala (2009) dalam Sugiono dan Pratista (2018) mengemukakan bahwa lingkungan kerja yang sehat, aman dan nyaman mampu meningkatkan produktivitas karyawan karena lingkungan kerja dengan kriteria sebagaimana yang disebutkan itu akan menimbulkan rasa senang dalam diri karyawan. Dengan kata lain, lingkungan kerja yang baik tidak hanya mampu untuk menunjang dan mendukung pelaksanaan tugas dan pekerjaan secara produktif oleh karyawan dalam perusahaan, tetapi juga mampu untuk memberikan keamanan dan kenyamanan bagi karyawan tersebut yang pada akhirnya akan menimbulkan perasaan puas di dalam diri karyawan yang bersangkutan.

$\mathrm{H}_{2}$ : Lingkungan kerja berpengaruh positif dan signifikan terhadap kepuasan kerja karyawan pada PT Astra Daihatsu Cabang Pasar Minggu

\section{Keterkaitan antara Motivasi dan Kepuasan Kerja}

Parimita, dkk. (2018) berhasil membuktikan bahwa variabel motivasi mampu mempengaruhi kepuasan kerja karyawan secara positif dan signifikan. Dalam hal ini, motivasi tepat yang diberikan oleh perusahaan kepada karyawannya akan mendorong karyawan untuk menyenangi pekarjaannya atau dengan kata lain motivasi tersebut akan mampu membuat karyawan yang bersangkutan merasa puas dengan pekerjaan yang dijalaninya.

Menurut Gustituati (2009), karyawan yang bermotivasi tinggi cenderung akan memiliki keinginan yang kuat untuk berhasil dalam pekerjaannya, sehingga akan bekerja secara bersemangat, giat, tekun, bersungguh-sungguh, aktif, kreatif, dan bertanggung jawab. Sementara itu, karyawan yang tidak memperoleh motivasi dalam bentuk imbalan kerja, misalnya, yang sesuai dengan ekspektasinya justru cenderung akan menjadi tidak maksimal dalam menghasilkan output karena tidak terpenuhinya kebutuhan karyawan tersebut. Hal ini pada akhirnya akan menimbulkan dampak psikologi berupa ketidakpuasan kerja (Turmono, 2018).

$\mathrm{H}_{3}$ : Motivasi berpengaruh positif dan signifikan terhadap kepuasan kerja karyawan pada PT Astra Daihatsu Cabang Pasar Minggu

\section{Kerangka Pemikiran}

Kerangka pemikiran dari penelitian ini dapat dilihat pada gambar sebagai berikut. 


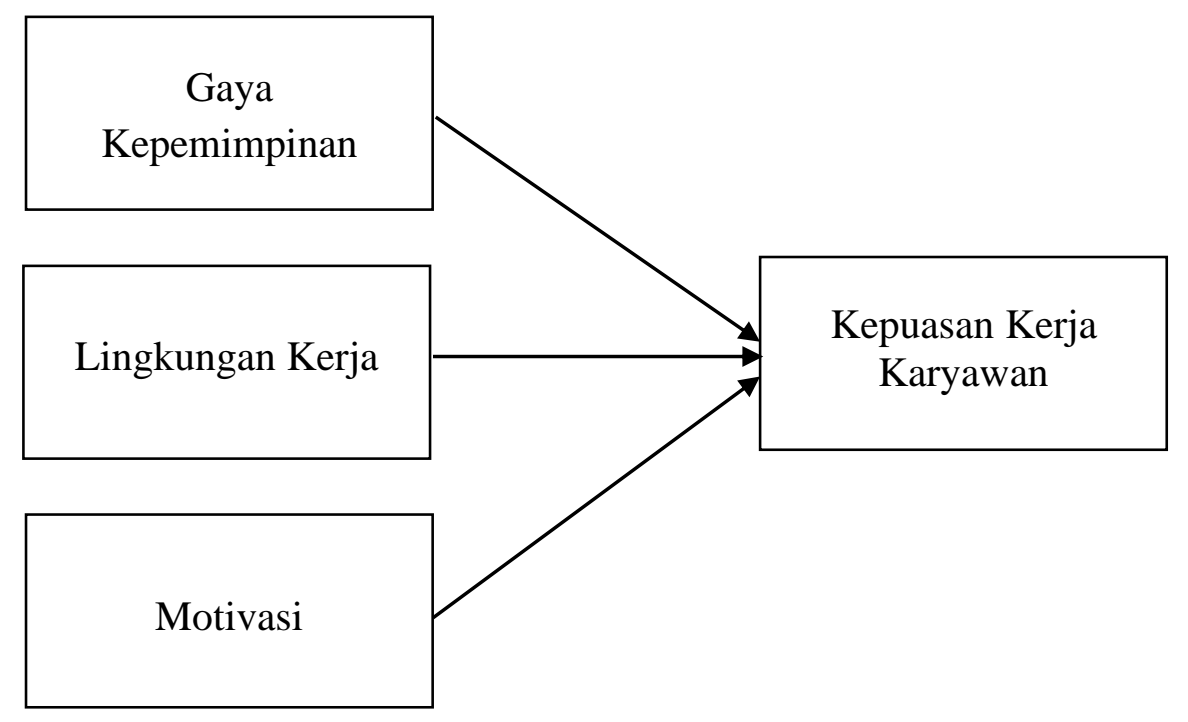

Gambar 1. Kerangka Pemikiran

\section{METODOLOGI PENELITIAN}

\section{Sumber dan Jenis Data}

Penelitian ini menggunakan data primer yang diperoleh dari hasil penyebaran kuesioner kepada responden yang bersangkutan untuk kemudian ditranslasikan ke dalam bentuk data kuantitatif dengan mempergunakan skala Likert. Jenis data tersebut dikategorikan sebagai data cross section.

\section{Populasi dan Sampel}

Populasi dari penelitian ini adalah seluruh karyawan PT Astra Daihatsu Cabang Pasar Minggu yang berjumlah sebanyak 100 orang. Dengan mempergunakan teknik probability sampling (random sample), banyaknya sampel yang digunakan adalah 80 responden.

\section{Metode Analisis}

Data dalam penelitian ini dianalisis menggunakan regresi linear berganda dengan alat bantu berupa program SPSS versi 22.0. Model regresi yang dipergunakan ditujukan untuk menganalisis pengaruh gaya kepemimpinan, lingkungan kerja, dan motivasi terhadap kepuasan kerja karyawan pada PT Astra Daihatsu Cabang Pasar Minggu dengan formula yang dirumuskan sebagai berikut. 


$$
\mathrm{Y}=\alpha+\mathrm{b}_{1} \mathrm{X}_{1}+\mathrm{b}_{2} \mathrm{X}_{2}+\mathrm{b}_{3} \mathrm{X}_{3}+\mathrm{e}
$$

Keterangan:

$\begin{array}{ll}\mathrm{Y} & =\text { Kepuasan kerja karyawan } \\ \alpha & =\text { Konstanta } \\ \mathrm{b}_{1}, \mathrm{~b}_{2}, \mathrm{~b}_{3} & =\text { Koefisien regresi } \\ \mathrm{X}_{1} & =\text { Gaya kepemimpinan } \\ \mathrm{X}_{2} & =\text { Lingkungan kerja } \\ \mathrm{X}_{3} & =\text { Motivasi } \\ \mathrm{e} & =\text { Tingkat kesalahan }\end{array}$

\section{HASIL DAN PEMBAHASAN}

Instrumen yang dipergunakan pada penelitian ini sebelumnya sudah dinyatakan valid dan reliabel berdasarkan hasil pengujian validitas dan reliabilitas yang sudah terlebih dahulu dilakukan. Selain itu, data penelitian dan model regresi yang dipergunakan juga terbukti telah memenuhi syarat-syarat asumsi klasik berdasarkan uji asumsi-asumsi klasik yang telah dilakukan sebelumnya.

\section{Hasil Uji Regresi Linear Berganda}

Adapun hasil pengujian regresi linear berganda dirumuskan ke dalam persamaan sebagai berikut.

$$
Y=21,829+0,274 X_{1}+0,166 X_{2}+0,161 X_{3}+e
$$

Keterangan:

$$
\begin{array}{ll}
\mathrm{Y} & =\text { Kepuasan kerja karyawan } \\
\mathrm{X}_{1} & =\text { Gaya kepemimpinan } \\
\mathrm{X}_{2} & =\text { Lingkungan kerja } \\
\mathrm{X}_{3} & =\text { Motivasi } \\
\mathrm{e} & =\text { Tingkat kesalahan }
\end{array}
$$

\section{Hasil Uji F}

Dari hasil uji $\mathrm{F}$, diperoleh nilai $\mathrm{F}_{\text {hitung }}$ sebesar 31,670 dengan nilai sig. (p-value) sebesar 0,000. Berdasarkan hal tersebut, diketahui bahwa nilai $F_{\text {hitung }}(31,670)>F_{\text {tabel }}$ 
$(2,72)$, sementara nilai sig. $(0,000)<\alpha(0,05)$, sehingga gaya kepemimpinan, lingkungan kerja, dan motivasi secara simultan terbukti berpengaruh signifikan terhadap kepuasan kerja karyawan.

\section{Hasil Uji Koefisien Determinasi}

Nilai koefisien determinasi dari model ini adalah 0,538. Hal tersebut mencerminkan bahwa variabel gaya kepemimpinan, lingkungan kerja, dan motivasi memiliki kontribusi sebesar 53,8\% dalam menjelaskan variabel kepuasan kerja karyawan. Sementara itu, 46,2\% lainnya dijelaskan oleh variabel lain di luar model penelitian.

\section{Hasil Uji Hipotesis (Uji t)}

Pada derajat kebebasan $(\mathrm{n}-\mathrm{k})=77$ dan tingkat signifikansi 0,05/2 = 0,025, diperoleh nilai $\mathrm{t}_{\text {tabel }}$ sebesar 1,99125 . Adapun hasil uji t dapat dilihat pada tabel sebagai berikut.

\section{Tabel 2. Hasil Uji t}

\begin{tabular}{|l|c|c|}
\hline \multicolumn{1}{|c|}{ Variabel } & thitung & Sig. \\
\hline Gaya Kepemimpinan $\left(\mathrm{X}_{1}\right)$ & 4,151 & 0,000 \\
\hline Lingkungan Kerja $\left(\mathrm{X}_{2}\right)$ & 2,977 & 0,004 \\
\hline Motivasi $\left(\mathrm{X}_{3}\right)$ & 4,110 & 0,000 \\
\hline
\end{tabular}

(Sumber: Data diolah, 2019)

Berikut ini merupakan interpretasi dari tabel di atas.

1. Variabel gaya kepemimpinan memiliki nilai thitung sebesar 4,151 dengan nilai signifikansi sebesar 0,000, sehingga diketahui bahwa $t_{\text {hitung }}>t_{\text {tabel }}(4,151>1,99125)$ dan nilai signifikansi $0,000<0,05$. Hal tersebut menunjukkan bahwa $\mathrm{H}_{0}$ ditolak dan $\mathrm{H}_{1}$ diterima, sehingga terbukti bahwa gaya kepemimpinan berpengaruh positif dan signifikan terhadap kepuasan kerja karyawan pada PT Astra Daihatsu Cabang Pasar Minggu.

2. Variabel lingkungan kerja memiliki nilai thitung sebesar 2,977 dengan nilai signifikansi sebesar 0,004 , sehingga diketahui bahwa $t_{\text {hitung }}>t_{\text {tabel }}(2,977>1,99125)$ dan nilai signifikansi $0,004<0,05$. Hal tersebut menunjukkan bahwa $\mathrm{H}_{0}$ ditolak dan $\mathrm{H}_{2}$ diterima, sehingga terbukti bahwa lingkungan kerja berpengaruh positif dan signifikan terhadap kepuasan kerja karyawan pada PT Astra Daihatsu Cabang Pasar Minggu.

3. Variabel motivasi memiliki nilai $t_{\text {hitung }}$ sebesar 4,110 dengan nilai signifikansi sebesar 0,000 , sehingga diketahui bahwa $t_{\text {hitung }}>t_{\text {tabel }}(4,110>1,99125)$ dan nilai signifikansi 
$0,000<0,05$. Hal tersebut menunjukkan bahwa $\mathrm{H}_{0}$ ditolak dan $\mathrm{H}_{3}$ diterima, sehingga terbukti bahwa motivasi berpengaruh positif dan signifikan terhadap kepuasan kerja karyawan pada PT Astra Daihatsu Cabang Pasar Minggu.

\section{Pembahasan}

\section{Pengaruh Gaya Kepemimpinan terhadap Kepuasan Kerja Karyawan}

Gaya kepemimpinan terbukti berpengaruh positif dan signifikan terhadap kinerja karyawan PT Astra Daihatsu Cabang Pasar Minggu berdasarkan hasil penelitian ini. Hal tersebut menunjukkan bahwa semakin baik gaya kepemimpinan yang diterapkan pada perusahaan, maka semakin tinggi kepuasan kerja yang dirasakan oleh karyawan dari perusahaan tersebut. Sebaliknya, semakin buruk gaya kepemimpinan yang diterapkan pada perusahaan, maka semakin rendah kepuasan kerja yang dirasakan oleh karyawan dari perusahaan tersebut.

Hasil penelitian ini mendukung hasil penelitian sebelumnya yang dilakukan oleh Yanoto (2018) yang menunjukkan bahwa gaya kepemimpinan secara positif dan signifikan berpengaruh terhadap kepuasan kerja karyawan. Hal tersebut terjadi karena gaya kepemimpinan itu sendiri akan menentukan pendekatan yang akan dipergunakan oleh seorang pemimpin perusahaan dalam mengarahkan karyawan yang dipimpinnya untuk mencapai suatu tujuan, sehingga apabila gaya kepemimpinan yang diterapkan tidaklah tepat, maka pendekatan yang dipergunakan oleh pimpinan tersebut pun menjadi tidak tepat, sehingga dapat menimbulkan ketidakpuasan di dalam diri karyawan yang bersangkutan.

Khan, et al. (2012) dalam Sugiono dan Rachmawati (2019) mengilustrasikan bahwa pemimpin dengan gaya kepemimpinan transformasional, misalnya, cenderung akan memberi karyawannya lebih banyak kesempatan untuk berkreasi melalui otonomi. Secara lebih lanjut, Sugiono dan Pratista (2018) menjelaskan bahwa pemberian lebih banyak kesempatan kepada karyawan untuk berkreasi tersebut akan membuat karyawan yang bersangkutan menjadi lebih mampu untuk menciptakan dan mengembangkan gagasannya untuk kepentingan perusahaan, sehingga karyawan tersebut akan memberikan kontribusi yang lebih besar kepada perusahaan tersebut. Hal tersebut pada akhirnya akan menimbulkan kepuasan tersendiri di dalam diri karyawan karena ia merasa telah mampu untuk berkontribusi secara lebih signifikan terhadap perusahaan tempatnya bekerja. Adapun pada perusahaan dengan pemimpin yang bergaya kepemimpinan demokratis, 
Nopitasari dan Krisnandi (2018) mengemukakan bahwa karyawan cenderung akan merasa dilibatkan oleh pimpinannya. Oleh karena karyawan merasa dirinya dianggap oleh perusahaan tempatnya bekerja dan bahkan diberikan tanggung jawab untuk terlibat dalam pengambilan keputusan, maka kepuasan pun akan timbul di dalam diri karyawan tersebut.

\section{Pengaruh Lingkungan Kerja terhadap Kepuasan Kerja Karyawan}

Lingkungan kerja terbukti berpengaruh positif dan signifikan terhadap kinerja karyawan PT Astra Daihatsu Cabang Pasar Minggu berdasarkan hasil penelitian ini. Hal tersebut menunjukkan bahwa semakin baik lingkungan kerja pada perusahaan, maka semakin tinggi kepuasan kerja yang dirasakan oleh karyawan dari perusahaan tersebut. Sebaliknya, semakin buruk lingkungan kerja pada perusahaan, maka semakin rendah kepuasan kerja yang dirasakan oleh karyawan dari perusahaan tersebut.

Hasil penelitian ini mendukung hasil penelitian sebelumnya yang dilakukan oleh Sitinjak (2018) yang menunjukkan bahwa lingkungan kerja secara positif dan signifikan berpengaruh terhadap kepuasan kerja karyawan. Dalam kaitannya dengan hal ini, Rivai dan Sagala (2009) dalam Sugiono dan Pratista (2018) mengemukakan bahwa lingkungan kerja yang sehat, aman dan nyaman mampu meningkatkan produktivitas karyawan karena lingkungan kerja dengan kriteria sebagaimana yang disebutkan itu akan menimbulkan rasa senang dalam diri karyawan. Dengan kata lain, lingkungan kerja yang baik tidak hanya mampu untuk menunjang dan mendukung pelaksanaan tugas dan pekerjaan secara produktif oleh karyawan dalam perusahaan, tetapi juga mampu untuk memberikan keamanan dan kenyamanan bagi karyawan tersebut yang pada akhirnya akan menimbulkan perasaan puas di dalam diri karyawan yang bersangkutan.

\section{Pengaruh Motivasi terhadap Kepuasan Kerja Karyawan}

Motivasi terbukti berpengaruh positif dan signifikan terhadap kinerja karyawan PT Astra Daihatsu Cabang Pasar Minggu berdasarkan hasil penelitian ini. Hal tersebut menunjukkan bahwa semakin baik motivasi yang diberikan oleh perusahaan kepada karyawannya, maka semakin tinggi kepuasan kerja yang dirasakan oleh karyawan tersebut terhadap perusahaan yang bersangkutan. Sebaliknya, semakin buruk motivasi yang diberikan oleh perusahaan kepada karyawannya, maka semakin rendah kepuasan kerja yang dirasakan oleh karyawan tersebut terhadap perusahaan yang bersangkutan. 
Hasil penelitian ini mendukung hasil penelitian sebelumnya yang dilakukan oleh Parimita, dkk. (2018) yang menunjukkan bahwa motivasi secara positif dan signifikan berpengaruh terhadap kepuasan kerja karyawan. Dalam hal ini, motivasi tepat yang diberikan oleh perusahaan kepada karyawannya akan mendorong karyawan untuk menyenangi pekarjaannya atau dengan kata lain motivasi tersebut akan mampu membuat karyawan yang bersangkutan merasa puas dengan pekerjaan yang dijalaninya.

Menurut Gustituati (2009) dalam Turmono (2018), karyawan yang bermotivasi tinggi cenderung akan memiliki keinginan yang kuat untuk berhasil dalam pekerjaannya, sehingga akan bekerja secara bersemangat, giat, tekun, bersungguh-sungguh, aktif, kreatif, dan bertanggung jawab. Suryadi dan Efendi (2018) mengemukakan bahwa pegawai juga cenderung akan menyenangi pekerjaannya bila telah termotivasi secara intrinsik. Adapun karyawan yang tidak memperoleh motivasi dalam bentuk imbalan kerja, misalnya, yang sesuai dengan ekspektasinya justru cenderung akan menjadi tidak maksimal dalam menghasilkan output karena tidak terpenuhinya kebutuhan karyawan tersebut. Hal ini pada akhirnya akan menimbulkan dampak psikologi berupa ketidakpuasan kerja (Turmono, 2018).

Menurut Manullang (2001) dalam Sugiono dan Rachmawati (2019), perusahaan yang tidak memberikan motivasi ekstrinsik yang sebanding kepada karyawannya, misalnya dalam bentuk kondisi kerja, upah, tunjangan, dan jaminan keselamatan kerja yang mencukupi, biasanya juga akan menghadapi masalah tingkat ketidakhadiran karyawan yang tinggi. Hal tersebut pada dasarnya juga disebabkan oleh ketidakpuasan karyawan terhadap motivasi yang diberikan oleh perusahaan.

\section{KESIMPULAN DAN SARAN}

\section{Kesimpulan}

Berdasarkan hasil penelitian ini, Penulis dapat menyimpulkan hal-hal sebagai berikut.

1. Gaya kepemimpinan berpengaruh positif dan signifikan terhadap kinerja karyawan pada PT Astra Daihatsu Cabang Pasar Minggu.

2. Lingkungan kerja berpengaruh positif dan signifikan terhadap kinerja karyawan pada PT Astra Daihatsu Cabang Pasar Minggu.

3. Motivasi berpengaruh positif dan signifikan terhadap kinerja karyawan pada PT Astra Daihatsu Cabang Pasar Minggu. 


\section{Saran}

Berdasarkan kesimpulan di atas, dikemukakan saran-saran sebagai berikut.

1. Perusahaan diharapkan senantiasa memastikan bahwa gaya kepemimpinan yang diterapkannya merupakan gaya kepemimpinan yang cocok bagi karyawannya, yakni gaya yang tidak menimbulkan hubungan yang kaku antara pimpinan dan karyawan.

2. Perusahan diharapkan senantiasa mengatur dan memelihara lingkungan kerjanya sedemikian rupa agar lingkungan kerja tersebut dapat menimbulkan kenyamanan dan keamanan bagi karyawannya serta dapat memfasilitasi segala aktivitas kerja karyawan, sehingga karyawan tidak memiliki hambatan dalam melaksanakan segala aktivitas penunjang kerja perusahaan.

3. Perusahaan diharapkan dapat senantiasa memberikan motivasi dalam bentuk yang tepat bagi karyawannya agar dapat meningkatkan semangat dan kepuasan kerja karyawan.

\section{DAFTAR PUSTAKA}

Bangun, W. 2012. Manajemen Sumber Daya Manusia. Erlangga. Jakarta.

Gustituati, N. 2009. Manajemen Pendidikan Landasan Teori dan Perkembangannya. UNP Press. Padang.

Handoko, T.H. 2012. Manajemen Personalia dan Sumber Daya Manusia. BPFE. Yogyakarta.

Hariandja, M.T.E. 2005. Manajemen Sumber Daya Manusia. Grasindo. Jakarta.

Hasibuan, M.S.P. 2014. Manajemen Sumber Daya Manusia.Bumi Aksara. Jakarta.

Khan, V., M.H. Hafeez, S.M.H. Rizvi, A. Hasnain, dan A. Mariam. 2012. Relationship of Leadership Styles, Employees Commitment and Organizatiion Performance: A Study on Customer Support Representatives. European Journal of Economics, Finance and Administrative Sciences. 49: 133-143.

Manullang, M. 2001. Manajemen Sumber Daya Manusia. BPFE. Yogyakarta.

Moeheriono. 2012. Pengukuran Kinerja Berbasis Kompetensi. Raja Grafindo Persada. Jakarta.

Nopitasari, E. dan H. Krisnandi. 2018. Pengaruh Gaya Kepemimpinan Demokratis, Motivasi Intrinsik dan Disiplin Kerja terhadap Kinerja Karyawan PT Pangansari Utama Food Industry. Jurnal Ilmu Manajemen Oikonomia. 14(1): 15-30.

Nitisemito, A.S. 2000. Manajemen Personalia. Ghalia Indonesia. Jakarta. 
Nuraini, T. 2013. Manajemen Sumber Daya Manusia. Yayasan Aini Syam. Pekan Baru.

Parimita, W., S. Khoriyah, dan A.W. Handaru. 2018. Pengaruh Motivasi Kerja dan Kompensasi terhadap Kepuasan Kerja pada Karyawan PT Tridaya Eramina Bahari. Jurnal Riset Manajemen Ssains Indonesia. 9(1): 125-144.

Rivai, V. dan D. Mulyadi. 2012. Kepemimpinan dan Perilaku Organisasi. Edisi Ketiga. Raja Grafindo Persada. Jakarta.

dan E.J. Sagala. 2009. Manajemen Sumber Daya Manusia untuk Perusahaan. Raja Grafindo Persada. Jakarta.

Robbins, S.P. 2001. Organizational Behavior. Ninth Edition. Prentice Hall. New Jersey. Terjemahan Tim Indeks. 2003. Perilaku Organisasi. Indeks. Jakarta.

. dan T.A. Judge. 2006. Organizational Behavior.12 ${ }^{\text {th }}$ Ed. Prentice Hall. New Jersey. Terjemahan D. Angelica, R. Cahyani dan A. Rosyid. 2008. Perilaku Organisasi. Edisi 12. Salemba Empat. Jakarta.

Sitinjak, L.N. 2018. Pengaruh Lingkungan Kerja terhadap Kepuasan Kerja Karyawan: Studi pada Karyawan PT Mitra Pinasthika Mustika Rent Tangerang Selatan. Jurnal Administrasi Bisnis. 60(2): 162-168.

Sofyan, D.K. 2013. Pengaruh Lingkungan Kerja terhadap Kinerja Kerja Pegawai BAPPEDA. Malikussaleh Industrial Engineering Journal. 2(1): 18-23.

Sofyandi, H. 2008. Manajemen Sumber Daya Manusia. Graha Ilmu. Yogyakarta.

Sugiono, E. dan R.M. Pratista. 2018. Pengaruh Kepemimpinan Transformasional, Motivasi dan Lingkungan Kerja Fisik terhadap Kinerja Karyawan PT Rafa Topaz Utama. Jurnal Ilmu Manajemen Oikonomia. 14(2): 43-58.

dan W. Rachmawati. 2019. Pengaruh Gaya Kepemimpinan Transformasional, Budaya Organisasi dan Motivasi Ekstrinsik terhadap Kinerja Karyawan PT Semen Padang, Jakarta Selatan. Jurnal Ilmu Manajemen Oikonomia. 15(1): 57-69.

Suryadi, I. dan S. Efendi. 2018. Pengaruh Motivasi Intrinsik, Kepuasan Kerja dan Budaya Organisasi terhadap Kinerja Pegawai Biro Kepegawaian di Badan Kepegawaian Negara Jakarta. Jurnal Ilmu Manajemen Oikonomia. 14(2): 109-122.

Sutrisno, E. 2010. Manajemen Sumber Daya Manusia. Kencana Prenada Media. Jakarta.

Turmono. 2018. Pengaruh Motivasi dan Lingkungan Kerja terhadap Kinerja Karyawan Pondok Indah Golf Apartment. Jurnal Ilmu Manajemen Oikonomia. 14(2): 95-108.

Tyssen, T.G. 1992. The First Time Manager: A Survival Gude. Self-Counsel Press. North Vancouver. Terjemahan A.H. Pudjaatmaka. 2003. Buku Petunjuk bagi Manajer Pemula. Arcan. Jakarta.

Wibowo. 2010. Manajemen Kinerja. Edisi Ketiga. Raja Grafindo Prasada. Jakarta. 
Yanoto, A. 2018. Pengaruh Gaya Kepemimpinan terhadap Kepuasan Kerja melalui Motivasi dan Kinerja Karyawan PT Nutrifood Indonesia di Surabaya. AGORA. 6(1). 